DOROTA BURCHART-KOROL, Ph.D. ${ }^{1}$

(Corresponding author)

E-mail: dorota.burchart-korol@polsı.pl

PIOTR FOLEGA, Ph.D. ${ }^{1}$

E-mail: piotr.folega@pols..pl

${ }^{1}$ Faculty of Transport

Silesian University of Technology

Krasińskiego 8, 40-019 Katowice, Poland
Traffic and Environment (Ecology)

Preliminary Communication

Submitted: 12 Sep. 2018

Accepted: 5 Feb. 2019

\title{
IMPACT OF ROAD TRANSPORT MEANS ON CLIMATE CHANGE AND HUMAN HEALTH IN POLAND
}

\begin{abstract}
Operation of means of transport is one of the major sources of environmental impact. The goal of this article is to analyse greenhouse gas emissions and to assess the impact of the operation of means of road transport in Poland on human health using the life cycle assessment technique based on an analysis of emission of dust and gas pollutants. Road transport was assessed by taking the following means of transport into account: passenger cars, other cars with weight of up to $3,500 \mathrm{~kg}$, lorries, buses, motorcycles, mopeds and tractors. It has been evidenced that the highest emissions of dust and gas pollutants are caused by passenger cars, which is mainly due to the number of vehicles of this type traversing Polish roads. The main cause of climate changes due to road transport is $\mathrm{CO}_{2}$ emission, while $\mathrm{NO}_{x}$ emission is the main factor determining individual categories of damage to human health. The negative environmental impact is primarily related to the operation of combustion engine vehicles. Diesel oil and petrol are currently the main fuels used in Polish transport. In order to reduce their impact on the environment, one should intensify the efforts aimed at increasing the share of alternative fuels in transport. Alternative fuels, particularly electricity, have become an important element in the development strategies of the automotive industry in Poland.
\end{abstract}

\section{KEY WORDS}

means of road transport; emission; life cycle assessment; climate change; human health;

\section{INTRODUCTION}

Means of road transport, while in operation, cause harmful consequences to human health as well as to the environment. This manifests itself in the increased emissions of harmful dust and gas pollutants, increased noise levels and the associated health loss of all road users. According to the European Environment Agency [1], transport is responsible for about one third of total energy consumption in the EEA member states and for more than one fifth of greenhouse gas (GHG) emissions. Emissions need to decrease by around two thirds by 2050, compared with the 1990 levels, to meet the long-term $60 \%$ GHG emission reduction target established in the Transport White Paper [2]. Reducing the GHG emission is one of the priorities of the European Commission. According to the European Strategy for Low-Emission Mobility, transport represents almost one fourth of Europe's GHG emission and is the main cause of air pollution in cities. It is important to know how these pollutants translate into specific consequences for the environment and the society. The type of fuel used in transport is an important factor in reducing harmful emissions [3]. The EU legislation requires the GHG intensity of vehicle fuels to be cut by as much as $10 \%$ by 2020 . The implementation of electromobility is primarily related to the reduction of the impact of the GHG emission caused by vehicles as well as the impact of hazardous exhaust gas emission on human health [4-7]. Paper [8] provides a calculation of the GHG emission of an electric vehicle compared to the GHG emission of a vehicle with an internal combustion engine.

The sector-specific activities undertaken in Poland in the field of transport with reference to the guidelines of the United Nations Framework Convention on Climate Change, assumed to trigger the reduction of the domestic greenhouse gas emission, include [9]:

- reducing the environmental nuisance of road transport;

- increasing the share of alternative fuels in transport;

- promoting e-mobility;

- upgrading railway infrastructure:

- purchasing modern and upgrading the existing rolling stock;

- supporting technical solutions offering increased energy efficiency of ships;

- introducing organisational measures to foster the reduction of emissions from aviation;

- improving public transport in cities;

- developing intermodal transport;

- promoting cycling as a means of transport.

The investments considered important for the reduction of the greenhouse gas emission caused by transport include development of transport networks 
alternative to road transport, such as the railway network, expansion of waterways, and implementation of projects related to the construction of an integrated and interconnected transport network that can be efficiently used for the sake of competitive economy, such as the National Railway Programme, development of the inland navigation sector and development of intermodal transport. There are additional plans to increase the share of eco-friendly transport in cities and their functional areas through promotion of public transport management mechanisms and its improvement, fostering efficient public transport organisation solutions, replacing the rolling stock used in urban transport with eco-friendly vehicles, and development of agglomeration rail passenger transport [9]. The Clean Transport Package for Poland rests on three pillars [10]: the E-mobility Development Plan for Poland, the national policy framework for the development of alternative fuel infrastructure and the establishment of a low-carbon transport fund. With regard to transport in Poland, there are many EU regulations in force, including those pertaining to standards for the environmental characteristics of vehicles. For instance, there are regulations amended in 2014 that impose limitations on the $\mathrm{CO} 2$ emission from new passenger cars and delivery vans, continuously updated regulations on the type approval of motor vehicles against the emission of pollutants, or the directive on the development of infrastructure of alternative fuels for transport. The foregoing body of regulations is complemented by national legal acts, including the Act of 16 December 2010 on public collective transport (Journal of Laws of 2016, item 1867, as amended), which imposed an obligation to develop plans for the sustainable development of public collective transport (transport plans) in cases when public transport administrators plan to organise transport services of the public utility nature. Strategic actions for sustainable development in road transport include the following:

- construction of motorways and express roads;

- improvement of energy efficiency and emissivity of road vehicles by introducing obligatory reduced limits of emission of pollutants from cars;

- promotion of public transport in cities and their functional areas;

- optimised traffic management based on integrated space, transport and low-emission planning, and dissemination of traffic management systems;

- promotion of environmentally aware behaviour among drivers and users of transport services by promulgating environmentally-friendly driving techniques; and

- supporting the development of non-motorised transport, and the dynamically developing cycling in particular.
Various environmental assessment techniques applicable to transport have been used for several years, including the WTW (well-to-wheel) and the LCA (life cycle assessment) [11-13]. Environmental analyses according to the WTW methodology cover the stages of raw material extraction, refining and distribution of fuels, as well as the fuel consumption phase, while the LCA analysis can be used for environmental assessment of fuel, cars or individual stages of the vehicle life cycle, e.g. the stage of production of specific means of transport, operation of vehicles or their recycling. The LCA method can be used for the purposes of environmental assessment within frameworks of various systems referred to as "cradle to grave", "cradle to gate" or "gate to gate", depending on the research objective and assumptions. The LCA method integrated with the LCC (life cycle costing) economic assessment method is a useful tool for choosing the most eco-friendly and cost-effective (eco-effective) solutions and may prove useful for decision-making in the automotive industry [14].

So far, the LCA results provided in the literature of the subject for road transport have mainly pertained to greenhouse gas emission and have not revealed the impact of individual means of transport by taking national conditions into consideration. The goal of this study is an environmental assessment of the means of road transport in Poland with regard to their operation. The article provides an analysis of the road transport structure in Poland, the dust and gas emission, including the emission of $\mathrm{CO}_{2}, \mathrm{CO}, \mathrm{N}_{2} \mathrm{O}, \mathrm{CH}_{4}, \mathrm{NO}_{x}, \mathrm{NMVOC}$ (non-methane volatile organic compounds), PM (particulate matter) and $\mathrm{SO}_{2}$, as well as the impact of dust and gas emission associated with the operation of means of road transport on greenhouse gas emission and damage to human health, including cases where the latter is due to organic and inorganic compounds.

\section{METHODOLOGY}

In order to identify the environmental issues caused by the operation of means of transport, an analysis based on life cycle assessment (LCA) was performed to assess the potential environmental impact of technologies and products on different categories of damage, including greenhouse gas emission and the impact on human health. The LCA is a technique which - among other functions - makes it possible to conduct environmental assessment of different impact categories based on survey data, including the emission of dust and gas pollutants. According to the new edition of ISO 14001:2015, for the first time, the life cycle approach has been taken into account in environmental analyses [15]. The LCA technique is referred to in international standards ISO 14040:2006 [16] and ISO 14044:2006 [17], according to which the LCA analysis should consist of four phases: 
1) Defining purpose and scope;

2) Life cycle inventory ( $\mathrm{LCl}$ ) analysis of inputs and outputs;

3) Life cycle impact assessment (LCIA);

\section{4) Interpretation.}

In the first phase, the system's functions, the functional unit, the system boundaries and the basic assumptions underlying the analysis should be defined. The phase of analysis of inputs and outputs, on the other hand, includes acquisition of all the data required to perform the LCA analysis.

The goal of this study is to assess the environmental impact of operation of means of transport. The results thus obtained were analysed with reference to the year of analysis, and that is why the functional unit assumed for the analyses was the number of kilometres driven by individual means of transport in 2014. One of the main goals underlying both the purpose and the scope of the identification phase in the LCA is to define the system boundaries. The analyses cover the system from gate to gate, which means that they only comprise the analysis of the dust and gas emission from the operation of transport means in Poland, and disregard the stage of production of individual means of transport as well as their recycling. The goal of these analyses was to identify determinants for the assessment of greenhouse gas emission and of the impact on human health caused by the operation of vehicles in Poland.

The study included an analysis of road transport vehicles perceived as a source of air pollution emissions. The LCA was performed using version 8 of the Simapro software along with the Ecoinvent 3 database. The assumptions for the environmental assessment and for the acquisition of data pertaining to the structure of the dust and gas emission caused by the operation of road transport vehicles in Poland were developed on the basis of the 2017 data retried from the Central Statistical Office presenting values for the year 2014 [18]. According to the paper [18], the data concerning the emissions from means of road transport with internal combustion engines have been provided by the National Centre for Emission Balancing and Management. The emissions attributable to means of road transport (including passenger cars, cars with the total weight of up to $3,500 \mathrm{~kg}$, heavy goods vehicles with the total weight of more than $3,500 \mathrm{~kg}$, buses with the total weight of more than $3,500 \mathrm{~kg}$, motorcycles, mopeds and agricultural tractors) were estimated as a product of fuel consumption and the specific emission factor determining the average mass of the given pollutant emitted as a consequence of combustion of a unit of fuel mass or as a product of the total annual kilometrage of vehicles of the given type (vehicle-kilometres) and the road emission factor determining the average mass of the given pollutant emitted for a kilometrage of $1 \mathrm{~km}$.
The next, i.e., the third phase of the life cycle impact assessment ( $\mathrm{LClA}$ ) consists of calculating the impact and the damage category values using selected methods. The LCIA phase may consist of four steps: classification, characterisation, standardisation and weighing. The classification and characterisation steps are obligatory, while standardisation and weighing are optional steps. Classification consists of assigning individual elements to the respective environmental impact categories. In the context of this study, these elements were the dust and gas emissions from the operation of individual means of transport. Each emission category can be assigned to a certain impact category, defined as a set's component defined in the chosen LCA method. Consequently, the classification consists of determining the environmental problem caused by the release of a specific emission. The impact category is a "class representing the analysed environmental issues to which the results of an analysis of the set of life cycle inputs and outputs can be assigned" [17]. Another obligatory stage of the LCIA is characterisation. Each impact category is assigned what is referred to as a characterisation parameter and an impact category indicator. The characterisation parameter is "used to transform the established results of the set analysis into a general unit of the category indicator" [19]. On the other hand, all the elements assigned to the impact category under the given environmental model contribute to the same environmental impact, which makes it possible to obtain a single value of the characterisation parameter, this being referred to as the impact category indicator. Further steps in the LCIA are standardisation and weighing. They are not obligatory in the LCA, and so they have not been taken into consideration in this study.

The potential environmental impacts of means of transport were assessed by application of the IMPACT 2002+ impact assessment method. The impact category and damage category indicators used in the IMPACT method have been described in detail in paper [19]. The IMPACT method enables the environmental indicators to be considered under different impact categories. The study addressed in the paper included assessment of the impact of gas and dust emission from the analysed means of transport on damage categories such as: greenhouse gas emission (climate change), impact on human health, respiratory inorganics and respiratory organics. The climate change (expressed as $\mathrm{CO} 2 \mathrm{eq}$, eq=equivalent) is defined as the impact of human emissions on the radiative forcing of the atmosphere. Global warming potentials (GWPs) were used as characterisation factors to assess and aggregate the interventions for the impact category of climate change. The disability-adjusted life year (DALY) indicator has been adopted in the IMPACT 2002+ impact assessment method to express the human health impact category. According to this method, the DALY 
indicator is used to quantify the burden of human disease resulting from environmental pollution and to attribute it to the life cycle. The damage to human health caused by specific diseases includes loss of life and loss of normal ability, both resulting in a reduction of healthy life years of individuals. As an indicator for direct measurement of health loss, the DALY can be defined as the total loss of healthy life years from the onset to the death [20]. The disability-adjusted life year (DALY) has been widely used since the 1990s in evaluating global and/or regional burden of diseases. As many environmental pollutants are hazardous to human health, the DALY is also recognized as an indicator to quantify the health impact of environmental pollution related to the disease burden. The DALY was developed by the World Health Organization (WHO) and the World Bank to quantify the burden of disease and injury on human populations in the Global Burden of Disease study. As a disease burden indicator, the DALY combines the estimation of the time lived with disability and the time lost due to premature mortality with adjustment by a set of social preference values [20].

The categories of the effect caused by respiratory inorganics and respiratory organics include inorganic compounds and organic compounds in the air the presence of which increases the likelihood of respiratory diseases [19].

\section{RESULTS AND DISCUSSION}

\subsection{Analysis of the structure of means of road transport in Poland}

As mentioned in paper [18], road transport in Poland comprises the following means: passenger cars, other cars with weight of up to $3,500 \mathrm{~kg}$, lorries, buses, motorcycles, mopeds and tractors. The most evident change observed in the structure of individual modes of transport in Poland for freight transport in the years 2005-2015 was the increase in the importance of road transport. As for passenger transport, the importance of car transport has dwindled over the recent years to the benefit of rail and air transport. What can be observed in road transport is an increase in fuel consumption and in the number of cars [9]. In the years 2005-2015, the total number of vehicles being registered was observed to have risen by almost $63 \%$, including the number of passenger cars increasing by almost 68\% and motorcycles by nearly 69\% (Table 1).

In 2014, in Poland, the share of vehicles with petrol engines came to $52.57 \%$, vehicles with diesel engines accounted for $34.23 \%$, vehicles fuelled with LPG (liquefied petroleum gas) $-13.14 \%$, while other vehicles accounted for as little as $0.06 \%$ (including those running on compressed natural gas $-0.04 \%$, and on electric energy - 0.02\%) (Figure 1). The share of vehicles powered by alternative fuels has been continuously growing in Poland [21].

Table 2 summarises data on the fuel types used by individual means of road transport in 2014. Table 3 presents basic data concerning emissions from the operation of road transport vehicles in Poland.

The increase in the $\mathrm{CO}_{2}$ emission is related to the growing share of all automotive vehicles in transport, while the $\mathrm{NO}_{\mathrm{x}}$ and PM emissions have been decreasing, most likely due to the stringent requirements following the implementation of specific EURO standards. The changes to the permissible emission limit values for petrol and diesel engines are stated against the EURO standards (I-VI) according to which atmospheric emission of pollutants must be reduced (which mainly applies to the $\mathrm{NO}_{\mathrm{x}}$ and $\mathrm{PM}$ emissions).

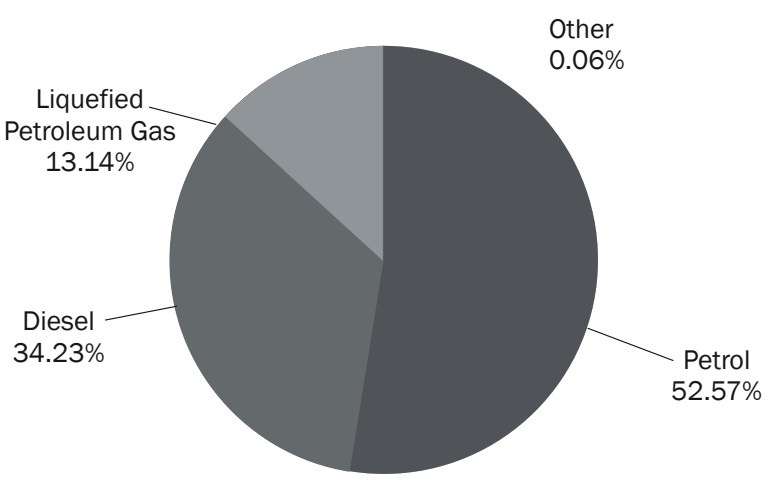

Figure 1 - Percentage share of fuels consumed in road transport in Poland in 2014 [21].

Table 1 - Vehicles registered in Poland in 2005 and in the years 2012-2015 (in '000 pcs.) [9]

\begin{tabular}{||l|c|c|c|c|c||}
\hline \multirow{2}{*}{\multicolumn{1}{|c|}{ Vehicles }} & \multicolumn{5}{c||}{ Years } \\
\cline { 2 - 6 } & 2005 & 2012 & 2013 & 2014 & 2015 \\
\hline \hline Total, including: & 16,816 & 24,876 & 25,684 & 26,472 & 27,409 \\
\hline Passenger cars & 12,339 & 18,744 & 19,389 & 20,004 & 20,723 \\
\hline Buses & 80 & 100 & 103 & 106 & 110 \\
\hline Lorries and road tractors & 2,305 & 3,178 & 3,242 & 3,341 & 3,428 \\
\hline Motorcycles & 754 & 1,107 & 1,153 & 1,190 & 1,272 \\
\hline Farm and ballast tractors & 1,243 & 1,596 & 1,633 & 1,669 & 1,703 \\
\hline \hline
\end{tabular}


Table 2 - Means of road transport according to the type of fuel consumed in 2014 [21]

\begin{tabular}{||l|c|c|c|c|c|c|c||}
\hline \multirow{2}{*}{ Fuel } & \multicolumn{2}{|c|}{ Passenger cars } & Lactors & Buses & $\begin{array}{c}\text { Special } \\
\text { purpose } \\
\text { vehicles }\end{array}$ & Total \\
\cline { 2 - 9 } & $\begin{array}{c}\text { Engine capacity } \\
\text { up to } 1,399 \mathrm{~cm}^{3}\end{array}$ & $\begin{array}{c}\text { Engine capacity } \\
\text { from 1,400 to } \\
1,999 \mathrm{~cm}^{3}\end{array}$ & Lorries & Tractors \\
\hline \hline Petrol & $6,826,175$ & $3,875,794$ & 668,881 & 1,621 & 4,168 & 25,427 & $11,402,066$ \\
\hline Diesel & 254,881 & $4,535,128$ & $2,114,224$ & 295,745 & 97,417 & 127,745 & $7,425,140$ \\
\hline $\begin{array}{l}\text { Liquefied Petroleum } \\
\text { Gas (LPG) }\end{array}$ & 857,330 & $1,803,999$ & 182,083 & 1,966 & 799 & 3,674 & $2,849,851$ \\
\hline $\begin{array}{l}\text { Compressed Natural } \\
\text { Gas (CNG) }\end{array}$ & 1,051 & 3,827 & 2,281 & 72 & 420 & 66 & 7,717 \\
\hline Electric Energy & 792 & 2,468 & 1,006 & 62 & 128 & 101 & 4,557 \\
\hline
\end{tabular}

Table 3 - Values of emission from the operation of means of road transport in Poland [18]

\begin{tabular}{||l|c|c|c|c|c|c||}
\hline \multicolumn{1}{|c|}{ Specification } & 2005 & 2010 & 2011 & 2012 & 2013 & 2014 \\
\hline \hline $\begin{array}{l}\mathrm{CO}_{2} \text { emission from means of road transport } \\
\text { in '000 mg }\end{array}$ & 32,734 & 46,466 & 47,001 & $45,123.3$ & $42,004.9$ & $42,332.6$ \\
\hline $\begin{array}{l}\mathrm{NO} \text { x emission from means of road transport } \\
\text { in '000 mg }\end{array}$ & 224.1 & 272.7 & 282.2 & 271.3 & 255.1 & 220.6 \\
\hline $\begin{array}{l}\text { Particulate matter (PM) emission from } \\
\text { means of road transport in '000 mg }\end{array}$ & 15.79 & 20.81 & 25.77 & 21.94 & 17.74 & 16.54 \\
\hline
\end{tabular}

\subsection{Emission of dust and gas pollutants from the means of transport subject to analysis}

Table 4 provides a summary of dust and gas emissions for the assumed means of transport subject to analysis.
The dust and gas emissions (Table 4) from road transport in Poland mainly comprise $\mathrm{CO}_{2}$ and $\mathrm{CO}$. The main sources of these emissions are passenger cars and others cars with the weight of up to $3,500 \mathrm{~kg}$. Passenger cars are responsible for $62.60 \%$ of $\mathrm{CO}_{2}$ and $79.62 \%$ of $\mathrm{CO}$ emission respectively, while $19.37 \%$ of

Table 4 - Emission of dust and gas pollutants from the analysed means of transport in 2014 [18]

\begin{tabular}{|c|c|c|c|c|c|c|c|c|c|}
\hline Substance & Unit & $\begin{array}{l}\text { Passenger } \\
\text { cars }\end{array}$ & $\begin{array}{c}\text { Other cars } \\
\text { - weight } \\
\text { up to } 3,500 \mathrm{~kg} \\
\end{array}$ & Lorries & Buses & $\begin{array}{l}\text { Motor- } \\
\text { cycles }\end{array}$ & Mopeds & Tractors & Total \\
\hline \multirow{2}{*}{$\mathrm{CO}_{2}$} & $\begin{array}{l}\text { thousand } \\
\text { tons }\end{array}$ & $26,501.80$ & $8,200.60$ & $4,838.30$ & $1,833.60$ & 77.20 & 35.70 & 845.40 & $42,332.60$ \\
\hline & share [\%] & 62.60 & 19.37 & 11.43 & 4.33 & 0.18 & 0.08 & 2.00 & 100 \\
\hline \multirow{2}{*}{$\mathrm{CO}$} & $\begin{array}{l}\text { thousand } \\
\text { tons }\end{array}$ & 448.35 & 57.92 & 20.26 & 6.43 & 12.03 & 5.80 & 12.32 & 563.11 \\
\hline & share [\%] & 79.62 & 10.29 & 3.60 & 1.14 & 2.14 & 1.03 & 2.19 & 100 \\
\hline \multirow{2}{*}{$\mathrm{N}_{2} \mathrm{O}$} & $\begin{array}{l}\text { thousand } \\
\text { tons }\end{array}$ & 1.14 & 0.39 & 0.20 & 0.03 & 0.00 & 0.00 & 0.04 & 1.80 \\
\hline & share [\%] & 63.33 & 21.67 & 11.11 & 1.67 & 0.00 & 0.00 & 2.22 & 100 \\
\hline \multirow{2}{*}{$\mathrm{CH}_{4}$} & $\begin{array}{l}\text { thousand } \\
\text { tons }\end{array}$ & 2.67 & 0.39 & 0.40 & 0.10 & 0.11 & 0.05 & 0.05 & 3.77 \\
\hline & share [\%] & 70.82 & 10.34 & 10.61 & 2.65 & 2.92 & 1.33 & 1.33 & 100 \\
\hline \multirow{2}{*}{$\mathrm{NO}_{x}$} & $\begin{array}{l}\text { thousand } \\
\text { tons }\end{array}$ & 110.77 & 38.48 & 41.89 & 14.57 & 0.16 & 0.03 & 16.84 & 222.74 \\
\hline & share [\%] & 49.73 & 17.28 & 18.81 & 6.54 & 0.07 & 0.01 & 7.56 & 100 \\
\hline \multirow[t]{2}{*}{ NMVOC } & $\begin{array}{l}\text { thousand } \\
\text { tons }\end{array}$ & 35.64 & 7.28 & 10.65 & 2.74 & 4.51 & 3.48 & 2.13 & 66.43 \\
\hline & share [\%] & 53.65 & 10.96 & 16.03 & 4.12 & 6.79 & 5.24 & 3.21 & 100 \\
\hline \multirow[t]{2}{*}{ PM } & $\begin{array}{l}\text { thousand } \\
\text { tons }\end{array}$ & 8.00 & 2.57 & 3.62 & 0.97 & 0.00 & 0.00 & 1.38 & 16.54 \\
\hline & share [\%] & 48.37 & 15.54 & 21.89 & 5.86 & 0.00 & 0.00 & 8.34 & 100 \\
\hline \multirow{2}{*}{$\mathrm{SO}_{2}$} & $\begin{array}{l}\text { thousand } \\
\text { tons }\end{array}$ & 0.72 & 0.24 & 0.15 & 0.06 & 0.00 & 0.00 & 0.03 & 1.20 \\
\hline & share [\%] & 60.00 & 20.00 & 12.50 & 5.00 & 0.00 & 0.00 & 2.50 & 100 \\
\hline
\end{tabular}


$\mathrm{CO}_{2}$ and $10.29 \%$ of $\mathrm{CO}$ emission is attributable to other cars. Passenger cars are also the main sources of all other dust and gas emissions subject to analysis, and they account for $63.33 \%$ of $\mathrm{N}_{2} \mathrm{O}, 70.82 \%$ of $\mathrm{CH}_{4}$, $49.73 \%$ of $\mathrm{NO}_{x}, 53.65 \%$ of $\mathrm{NMVOC}, 48.37 \%$ of $\mathrm{PM}$ and $60 \%$ of $\mathrm{SO}_{2}$.

\subsection{Greenhouse gas emission from the operation of means of transport in Poland}

Figure 2 illustrates the percentage share of individual means of transport in greenhouse gas emission, while Table 5 summarises the main factors which contribute to the GHG emission.

Figure 2 shows that passenger cars constitute the main source of greenhouse gas emission from road transport in Poland, which is mainly due to the number of cars of this category using roads. With regard to most means of transport, the main determinant of greenhouse gas emission is the emission of $\mathrm{CO}_{2}$, while for motorcycles and mopeds this emission type accounts for nearly $80 \%$, and CO emission accounts for ca. $20 \%$ of the total GHG emission (Table 5).

\subsection{Effect of the operation of means of transport in Poland on human health}

Figure 3 shows the percentage share of individual means of transport in the human health indicator, while Table 6 shows the human health indicator's main determinants.

Figure 3 shows that the dust and gas emissions from the operation of passenger cars constitute the main source of effect on the human health impact category in road transport in Poland (49.4\% share), while other factors are operation of lorries - 19.5\% and other cars - $16.9 \%$. With regard to all means of transport except for mopeds, the main determinants of the human health impact category are the $\mathrm{NO}_{\mathrm{x}}$ emission (from $71.2 \%$ to $77.8 \%$ ) and the PM emission for passenger cars, other cars, lorries, buses and tractors (from $21.8 \%$ to $26.6 \%$ ). For mopeds, it has been evidenced that the main determinants of effect on the human health indicator are the NMVOC emission (62.5\%) and the $\mathrm{NO}_{\mathrm{x}}$ emission (37.5\%) (Table 6).

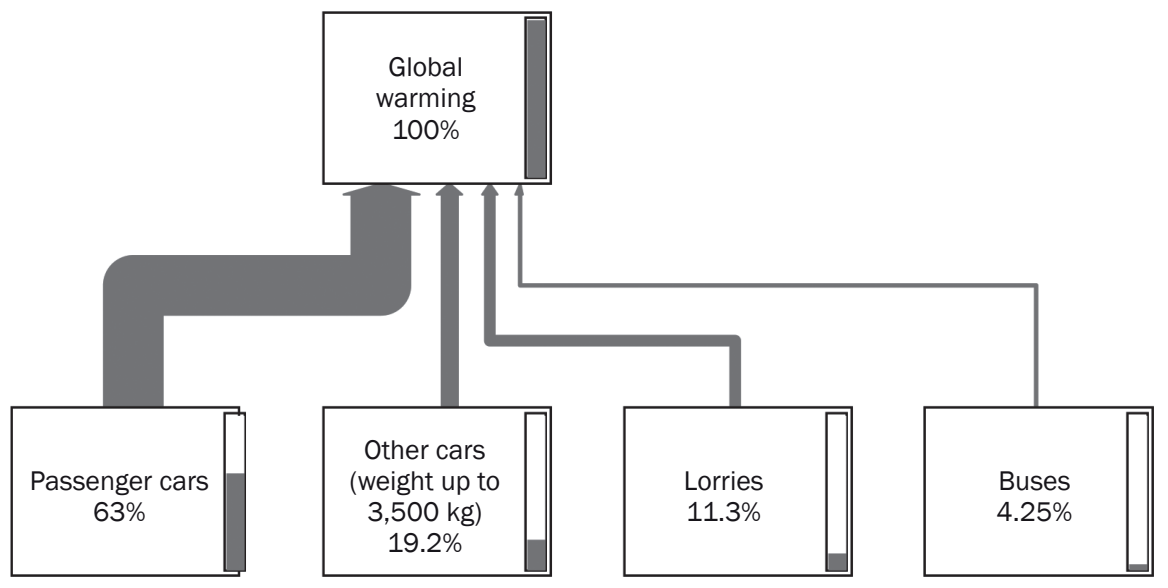

Figure 2 - Share of operation of individual means of transport in the greenhouse gas emission in Poland (data from 2014)

Table 5 - Determinants of greenhouse gas emission according to means of transport

\begin{tabular}{||l|c|c|c|c|c|c|c|c|c|c||}
\hline Substance & \multicolumn{2}{|c|}{$\mathrm{CO}_{2}$} & \multicolumn{2}{c|}{$\mathrm{CO}$} & \multicolumn{2}{c|}{$\mathrm{N}_{2} \mathrm{O}$} & \multicolumn{2}{c|}{$\mathrm{CH}_{4}$} & \multicolumn{2}{c||}{ Total } \\
\hline Unit & $\mathrm{kg} \mathrm{CO}_{2} \mathrm{eq}$ & $\%$ & $\mathrm{~kg} \mathrm{CO} 2 \mathrm{eq}$ & $\%$ & $\mathrm{~kg} \mathrm{CO} \mathrm{eq}_{2}$ & $\%$ & $\mathrm{~kg} \mathrm{CO}_{2} \mathrm{eq}$ & $\%$ & $\mathrm{~kg} \mathrm{CO}_{2}$ eq & $\%$ \\
\hline \hline Passenger cars & $2,65 \mathrm{E}+13$ & 96.7 & $7,04 \mathrm{E}+11$ & 2.6 & $1,78 \mathrm{E}+11$ & 0.6 & $2,03 \mathrm{E}+10$ & 0.1 & $2,74 \mathrm{E}+13$ & 100 \\
\hline Other cars & $8,20 \mathrm{E}+12$ & 98.1 & $9,09 \mathrm{E}+10$ & 1.1 & $6,08 \mathrm{E}+10$ & 0.7 & $2,96 \mathrm{E}+09$ & 0.0 & $8,36 \mathrm{E}+12$ & 100 \\
\hline Lorries & $4,84 \mathrm{E}+12$ & 98.8 & $3,18 \mathrm{E}+10$ & 0.6 & $3,12 \mathrm{E}+10$ & 0.6 & $3,04 \mathrm{E}+09$ & 0.1 & $4,90 \mathrm{E}+12$ & 100 \\
\hline Buses & $1,83 \mathrm{E}+12$ & 98.9 & $1,01 \mathrm{E}+10$ & 0.5 & $4,68 \mathrm{E}+09$ & 0.3 & $7,60 \mathrm{E}+08$ & 0.0 & $1,85 \mathrm{E}+12$ & 100 \\
\hline Motorcycles & $7,72 \mathrm{E}+10$ & 79.7 & $1,89 \mathrm{E}+10$ & 19.5 & 0 & 0.0 & $8,36 \mathrm{E}+08$ & 0.9 & $9,69 \mathrm{E}+10$ & 100 \\
\hline Mopeds & $3,57 \mathrm{E}+10$ & 79.0 & $9,11 \mathrm{E}+09$ & 20.2 & 0 & 0.0 & $3,80 \mathrm{E}+08$ & 0.8 & $4,52 \mathrm{E}+10$ & 100 \\
\hline Tractors & $8,45 \mathrm{E}+11$ & 97.0 & $1,93 \mathrm{E}+10$ & 2.2 & $6,24 \mathrm{E}+09$ & 0.7 & $3,80 \mathrm{E}+08$ & 0.0 & $8,71 \mathrm{E}+11$ & 100 \\
\hline Total & $4,23 \mathrm{E}+13$ & 97.2 & $8,84 \mathrm{E}+11$ & 2.0 & $2,81 \mathrm{E}+11$ & 0.6 & $2,87 \mathrm{E}+10$ & 0.1 & $4,35 \mathrm{E}+13$ & 100 \\
\hline
\end{tabular}




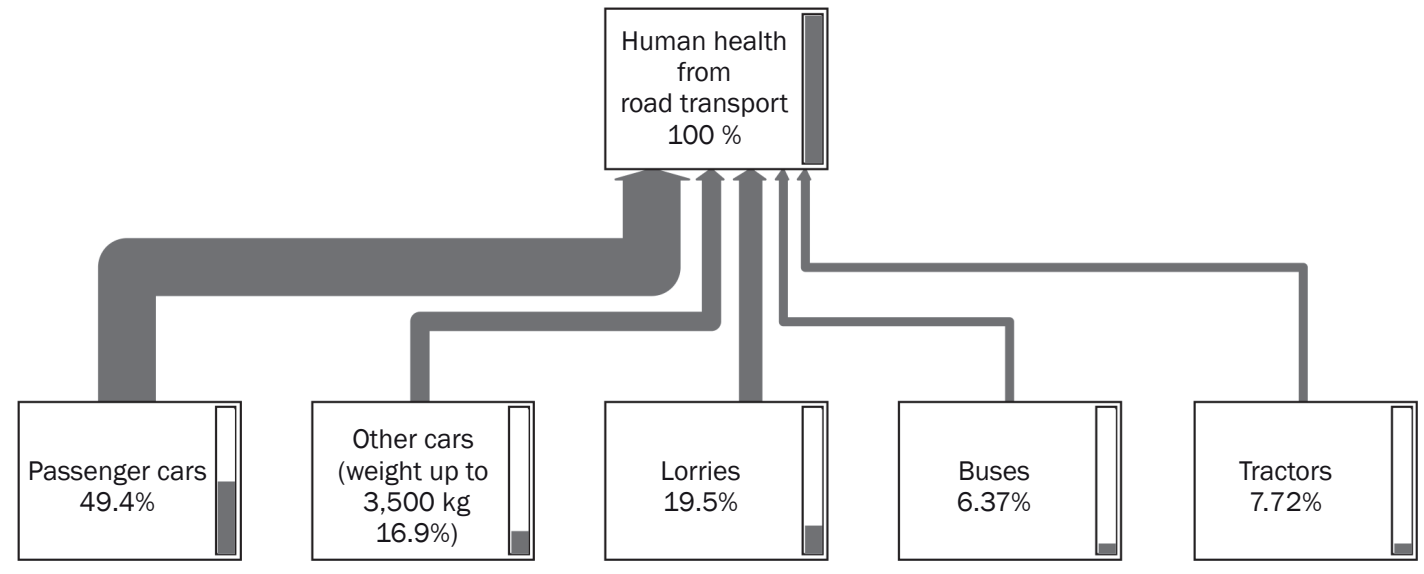

Figure 3 - Share of individual means of transport in the human health category (data from 2014)

Table 6 - Determinants of effect exerted by the operation of individual means of transport on the human health impact category

\begin{tabular}{|c|c|c|c|c|c|c|c|c|c|c|}
\hline Substance & \multicolumn{2}{|l|}{$\mathrm{NO}_{\mathrm{x}}$} & \multicolumn{2}{|c|}{ NMVOC } & \multicolumn{2}{|l|}{ PM } & \multicolumn{2}{|c|}{$\mathrm{SO}_{2}$} & \multicolumn{2}{|l|}{ Total } \\
\hline Unit & DALY & $\%$ & DALY & $\%$ & DALY & $\%$ & DALY & $\%$ & DALY & $\%$ \\
\hline Passenger cars & $9,869,607$ & 76.2 & $45,619.2$ & 0.4 & $3,000,375$ & 23.2 & 39,312 & 0.3 & $12,954,913.2$ & 100 \\
\hline Other cars & $3,428,568$ & 77.7 & $9,318.4$ & 0.2 & 963,750 & 21.8 & 13,104 & 0.3 & $4,414,740.4$ & 100 \\
\hline Lorries & $3,732,399$ & 73.0 & 1,3632 & 0.3 & $1,357,500$ & 26.6 & 8,190 & 0.2 & $5,111,721.0$ & 100 \\
\hline Buses & $1,298,187$ & 77.8 & $3,507.2$ & 0.2 & 363,750 & 21.8 & 3,276 & 0.2 & $1,668,720.2$ & 100 \\
\hline Motorcycles & 14,256 & 71.2 & $5,772.8$ & 28.8 & 0 & 0 & 0 & 0 & $20,028.8$ & 100 \\
\hline Mopeds & 2,673 & 37.5 & $4,454.4$ & 62.5 & 0 & 0 & 0 & 0 & $7,127.4$ & 100 \\
\hline Tractors & $1,500,444$ & 74.2 & $2,726.4$ & 0.1 & 517,500 & 25.6 & 1,638 & 0.1 & $2,022,308.4$ & 100 \\
\hline Total HH & $19,846,134$ & 75.7 & $85,030.4$ & 0.3 & $6,202,875$ & 23.7 & 65,520 & 0.3 & $26,199,559.4$ & 100 \\
\hline
\end{tabular}

Table 7 - Determinants of effect on the impact category of respiratory inorganics attributable to individual means of transport

\begin{tabular}{||l|c|c|c|c|c|c|c|c||}
\hline \hline Substance & \multicolumn{2}{|c|}{$\mathrm{NO}_{\mathrm{x}}$} & \multicolumn{2}{c|}{$\mathrm{PM}$} & \multicolumn{2}{c||}{$\mathrm{SO}_{2}$} & \multicolumn{2}{c||}{ Total } \\
\hline Unit & $\mathrm{kg} \mathrm{PM}_{2.5} \mathrm{eq}$ & $\%$ & $\mathrm{~kg} \mathrm{PM}$ \\
2.5 & $\mathrm{eq}$ & $\%$ & $\mathrm{~kg} \mathrm{PM}_{2.5} \mathrm{eq}$ & $\%$ & $\mathrm{~kg} \mathrm{PM}_{2.5}$ eq & $\%$ \\
\hline \hline Passenger cars & $1,41 \mathrm{E}+10$ & 76.6 & $4,29 \mathrm{E}+09$ & 23.3 & $5,62 \mathrm{E}+07$ & 0.3 & $1,84 \mathrm{E}+10$ & 100 \\
\hline Other cars & $4,90 \mathrm{E}+09$ & 77.9 & $1,38 \mathrm{E}+09$ & 21.9 & $1,87 \mathrm{E}+07$ & 0.3 & $6,29 \mathrm{E}+09$ & 100 \\
\hline Lorries & $5,33 \mathrm{E}+09$ & 73.2 & $1,94 \mathrm{E}+09$ & 26.6 & $1,17 \mathrm{E}+07$ & 0.2 & $7,28 \mathrm{E}+09$ & 100 \\
\hline Buses & $1,85 \mathrm{E}+09$ & 77.7 & $5,20 \mathrm{E}+08$ & 21.8 & $4,68 \mathrm{E}+06$ & 0.2 & $2,38 \mathrm{E}+09$ & 100 \\
\hline Motorcycles & $20,365,714$ & 100.0 & 0 & 0 & 0 & 0 & $20,365,714$ & 100 \\
\hline Mopeds & $3,818,571.4$ & 100.0 & 0 & 0 & 0 & 0 & $3,818,571.4$ & 100 \\
\hline Tractors & $2,14 \mathrm{E}+09$ & 74.0 & $7,39 \mathrm{E}+08$ & 25.6 & $2,34 \mathrm{E}+06$ & 0.1 & $2,89 \mathrm{E}+09$ & 100 \\
\hline Total & $2,84 \mathrm{E}+10$ & 76.1 & $8,86 \mathrm{E}+09$ & 23.8 & $9,36 \mathrm{E}+07$ & 0.3 & $3,73 \mathrm{E}+10$ & 100 \\
\hline
\end{tabular}

Table 8 - Determinants of effect on the impact category of respiratory organics attributable to individual means of transport

\begin{tabular}{||l|c|c|c|c|c|c||}
\hline \hline Substance & \multicolumn{2}{|c|}{$\mathrm{CH}_{4}$} & \multicolumn{2}{c|}{ NMVOC } & \multicolumn{2}{c||}{ Total } \\
\hline Unit & $\mathrm{kg} \mathrm{C}_{2} \mathrm{H}_{4} \mathrm{eq}$ & $\%$ & $\mathrm{~kg} \mathrm{C}_{2} \mathrm{H}_{4} \mathrm{eq}$ & $\%$ & $\mathrm{~kg} \mathrm{C}_{2} \mathrm{H}_{4}$ eq & $\%$ \\
\hline \hline Passenger cars & $1,60 \mathrm{E}+07$ & 0.1 & $2,14 \mathrm{E}+10$ & 99.9 & $2,14 \mathrm{E}+10$ & 100 \\
\hline Other cars & $2,34 \mathrm{E}+06$ & 0.2 & $4,37 \mathrm{E}+09$ & 99.8 & $4,38 \mathrm{E}+09$ & 100 \\
\hline Lorries & $2,40 \mathrm{E}+06$ & 0.1 & $6,40 \mathrm{E}+09$ & 99.9 & $6,40 \mathrm{E}+09$ & 100 \\
\hline Buses & $6,01 \mathrm{E}+05$ & 0.1 & $1,65 \mathrm{E}+09$ & 99.9 & $1,65 \mathrm{E}+09$ & 100 \\
\hline Motorcycles & $6,61 \mathrm{E}+05$ & 0.1 & $2,71 \mathrm{E}+09$ & 99.9 & $2,71 \mathrm{E}+09$ & 100 \\
\hline Mopeds & $3,00 \mathrm{E}+05$ & 0.1 & $2,09 \mathrm{E}+09$ & 99.9 & $2,09 \mathrm{E}+09$ & 100 \\
\hline Tractors & $3,00 \mathrm{E}+05$ & 0.1 & $1,28 \mathrm{E}+09$ & 99.9 & $1,28 \mathrm{E}+09$ & 100 \\
\hline Total & $2,27 \mathrm{E}+07$ & 0.1 & $3,99 \mathrm{E}+10$ & 99.9 & $3,99 \mathrm{E}+10$ & 100 \\
\hline
\end{tabular}


Table 7 shows the main determinants of effect on the respiratory inorganics impact category indicator for individual means of transport, while Table 8 shows the main determinants of effect on the respiratory organics impact category indicator.

The values provided in Tables 7 and 8 evidence that the operation of passenger cars is the main source for the two impact categories in question. For all the means of road transport subject to analysis, the $\mathrm{NO}_{\mathrm{x}}$ emission is the main determinant of the respiratory inorganics indicator, while the NMVOC emission is the main determinant of the respiratory organics indicator.

\section{CONCLUSIONS}

Based on the environmental assessment of the means of road transport operated in Poland using the life cycle assessment technique, the greenhouse gas emission as well as the human health impact category have been analysed in relation to other categories, such as respiratory inorganics and respiratory organics. The calculations performed for this purpose include an analysis of the environmental impact exerted by the operation of individual means of transport.

It has been evidenced that the main source of effect on the overall greenhouse gas emission and human health is the emission of dust and gas pollutants caused by passenger cars, which is mainly due to the number of vehicles of this type operated in Poland.

It has also been demonstrated that the main cause of climate changes induced by road transport is $\mathrm{CO}_{2}$ emission, while $\mathrm{NO}_{\mathrm{x}}$ emission is the main factor determining the human health damage category and the respiratory inorganics effect category, and the main factor determining the effect category of respiratory inorganics is the emission of NMVOC. The negative environmental impact is primarily related to the operation of combustion engine vehicles. Diesel oil and petrol are currently the main fuels used in Polish transport. In order to reduce their impact on the environment, one should intensify the efforts aimed at increasing the share of alternative fuels in transport.

In Poland in the recent years more than $50 \%$ of the vehicles were petrol-driven. Diesel vehicles represented an average of $35 \%$ of the means of road transport. The other fuel used was LPG (average of 13\%). CNG only accounted for an average of $0.03 \%$. The contribution of electricity has been growing continuously since 2015, but the market share of these alternative fuels in transport in Poland did not exceed 0.09 \% in 2017 [22].

In Poland alternative fuels, particularly electricity, have become an important element in the development strategies of the automotive industry and electromobility development programs are being developed. These programs are a result of European Union activities aimed at the development of electromobility and alternative fuels in EU countries. The Electromobility Development Plan adopted by the Polish Council of Ministers in 2017 plans for one million electric vehicles on the road by 2025 . The Polish government has adopted a new law on electromobility aimed at increasing electric vehicles. New legislation in the form of the Act on Electromobility and Alternative Fuels sets out the legal framework for electric vehicles development. In Poland the Act of 11 January 2018 on Electromobility and Alternative Fuels came into force on 22 February of this year. It establishes a system of incentives for the promotion of the use of vehicles powered by alternative fuels, mainly electricity, and also introduces mechanisms for initiating investments in the necessary infrastructure. The Act introduces into Polish law the requirements of Directive 2014/94/EU of 22 October 2014 on the deployment of alternative fuels infrastructure.

The analyses addressed in this paper have shown that pollution emissions exert a very significant impact on human health, which is why technological innovations related to modern solutions applied in power transmission systems are so important. What has been shown with reference to these analyses is the importance of all efforts aimed at diversification of fuels for passenger cars used in Poland. The orientation of the actions involved in increasing the number of electric cars on Polish roads is the one to be pursued, as it is directly connected with the minimisation of dust and gas emission, leading to the reduction of indicators in the categories of climate change and human health.

The LCA technique used in the analysis may also serve the purposes of decision-making in respect of assessment of the environmental aspects of transport as well as forecasting of changes in the transport sector in relation to environmental problems.

It is planned that further studies should include a life cycle assessment concerning operation of vehicles running on alternative fuels as well as analyses of the total life cycle of a passenger car.

Dr hab. inż. DOROTA BURCHART-KOROL, prof. Pol.ŚI.

E-mail: dorota.burchart-korol@polsl.pl

Dr hab. inż. PIOTR FOLĘGA, prof. Pol.Śl.

E-mail: piotr.folega@polsl.pl

Wydział Transportu, Politechnika Śląska

UI. Krasińskiego 8, 40-019 Katowice, Polska

\section{WP $\ Y$ W TRANSPORTU DROGOWEGO NA ZMIANY KLIMATU I ZDROWIE LUDZKIE W POLSCE}

\section{STRESZCZENIE}

Eksploatacja środków transportu jest jednym z głównych źródeł oddziaływania na środowisko. Celem artykułu była analiza emisji gazów cieplarnianych oraz ocena wpływu na zdrowie człowieka eksploatacji środków transportu drogowego w Polsce z zastosowaniem techniki oceny cyklu życia na podstawie analizy emisji zanieczyszczeń pyłowo-gazowych. 
Ocenie poddano transport drogowy uwzględniając następujące środki transportu: samochody osobowe, inne samochody o masie do $3500 \mathrm{~kg}$, samochody ciężarowe, autobusy, motocykle, motorowery i ciągniki. Wykazano, że największą emisję zanieczyszczeń pyłowo-gazowych powodują samochody osobowe, co głównie wynika z liczby pojazdów tego typu poruszających się po polskich drogach. Stwierdzono również, że główną przyczyną zmian klimatu w transporcie drogowym jest emisja CO2, natomiast głównym czynnikiem wpływającym negatywnie na zdrowie człowieka jest emisja NOx. Negatywny wpływ na środowisko jest związany przede wszystkim z eksploatacją pojazdów z silnikiem spalinowym. Olej napędowy oraz benzyna stanowią obecnie główne paliwa stosowane $w$ transporcie $w$ Polsce. $W$ celu zmniejszenia ich wpływu na środowisko należy zintensyfikować działania zmierzające do zwiększenia udziału paliw alternatywnych w transporcie. W Polsce alternatywne paliwa, zwłaszcza energia elektryczna, stały się ważnym elementem strategii rozwoju branży motoryzacyjnej.

\section{SŁOWA KLUCZOWE}

środki transportu drogowego; emisja; ocena cyklu życia; zmiana klimatu; zdrowie ludzkie;

\section{REFERENCES}

[1] European Environmental Agency. EEA SIGNALS 2016: Towards clean and smart mobility - Transport and environment in Europe. Copenhagen 2016. Available at: https://www.eea.europa.eu/publications/signals2016/at_download/file [Accessed 17 July 2018].

[2] European Commission. White Paper - Roadmap to a Single European Transport Area - Towards a competitive and resource-efficient transport system. Brussels 2011. Available at: https://ec.europa.eu/transport/ themes/strategies/2011_white_paper_en [Accessed 17 July 2018].

[3] Rievaj V, Synák F. Does electric car produce emissions? Scientific Journal of Silesian University of Technology. Series Transport. 2017;94: 187-197. Available at: doi:10.20858/sjsutst.2017.94.17 [Accessed 19 July 2018].

[4] Casals L, Martinez-Laserna E, García B, Nieto N. Sustainability analysis of the electric vehicle use in Europe for $\mathrm{CO} 2$ emissions reduction. Journal of Cleaner Production. 2016;127; 425-437. Available at: doi:10.1016/j.jclepro.2016.03.120 [Accessed 7 August 2018].

[5] Choma EF, Lie Ugaya CM. Environmental impact assessment of increasing electric vehicles in the Brazilian fleet. Journal of Cleaner Production. 2017;152: 497507. Available at: doi:10.1016/j.jclepro.2015.07.091 [Accessed 7 August 2018].

[6] Fernandez RA. A more realistic approach to electric vehicle contribution to greenhouse gas emissions in the city. Journal of Cleaner Production. 2018;172: 949959. Available at: doi:10.1016/j.jclepro.2017.10.158 [Accessed 7 August 2018].

[7] Hawkins TR, Gausen O, Strømman A. Environmental impacts of hybrid and electric vehicles - a review. The International Journal of Life Cycle Assessment. 2012;17: 997-1014. Available at: doi:10.1007/ s11367-012-0440-9 [Accessed 7 August 2018].

[8] Muha R, Perosa A. Energy consumption and carbon footprint of an electric vehicle and a vehicle with an internal combustion engine. Transport Problems. 2018;13: 49-58. Available at: doi:10.20858/ tp.2018.13.2.5 [Accessed 10 September 2018].

[9] Siódmy raport rządowy i trzeci raport dwuletni dla konferencji stron ramowej Konwencji Narodów Zjednoczonych w sprawie zmian klimatu. Warszawa 2017. Available at: https://www.mos.gov.pl/fileadmin/user_ upload/mos/srodowisko/ochrona_powietrza/7_ Raport_Rzadowy_i_3_Raport_Dwuletni_POLSKA.pdf [Accessed 27 July 2018].

[10] Ministerstwo Energii. Plan Rozwoju Elektromobilności w Polsce: Energia do przyszłości. Warszawa 2017. Available at: https://www.gov.pl/documents/ 33372/436746/DIT_PRE_PL.pdf/ebdf4105ef77-91df-0ace-8fbb2dd18140 [Accessed 7 September 2018].

[11] Folęga P, Burchart-Korol D. Environmental assessment of road transport in a passenger car using the life cycle approach. Transport Problems. 2017;12: 147-153. Available at: doi:10.20858/tp.2017.12.2.14 [Accessed 7 August 2018].

[12] Moro A, Helmers E. A new hybrid method for reducing the gap between WTW and LCA in the carbon footprint assessment of electric vehicles. The International Journal of Life Cycle Assessment. 2017;22: 4-14. Available at: doi:10.1007/s11367-015-0954-z [Accessed 7 August 2018].

[13] Hegedić M, Štefanić N, Nikšić M. Assessing the Environmental Impact of the Self-propelled Bulk Carriage through LCA. Promet - Traffic \& Transportation. 2018;30(3): 257-266. Available at: doi:10.7307/ptt. v30i3.2445 [Accessed 7 August 2018].

[14] Czaplicka-Kolarz K, Burchart-Korol D, Krawczyk P. [Sensitive analysis of eco-efficiency of an energy production technology based on coal gasification]. Przemysł Chemiczny. 2014;93(11): 1910-1915. Polish. Available at: bwmeta1.element.baztech-10ac22b5f008-47f9-bbe6-6ae368720a8d [Accessed 7 August 2018].

[15] ISO 14001:2015. Environmental management systems - Requirements with guidance for use. Geneva, Switzerland: International Standards Organisation (ISO); 2015.

[16] ISO 14040:2006. Environmental management - Life cycle assessment - Principles and framework. Geneva, Switzerland: International Standards Organisation (ISO); 2006.

[17] ISO 14044:2006. Environmental management - Life cycle assessment - Requirements and guidelines. Geneva, Switzerland: International Standards Organisation (ISO); 2006.

[18] Central Statistical Office. Road transport in Poland in the years 2014, 2015. Warszawa 2017. Available at: http://stat.gov.pl/obszary-tematyczne/transporti-lacznosc/transport/transport-drogowy-w-polsce-wlatach-2014-i-2015,6,4.html [Accessed 19 August 2018].

[19] Humbert S, Schryver A, Bengoa X, Margni M, Jolliet O. IMPACT 2002+: User Guide; 2012. Available at: 
https://www.quantis-intl.com/pdf/IMPACT2002_ UserGuide_for_vQ2.21.pdf [Accessed 2 August 2018].

[20] Gao T, Wang XC, Chen R, Ngo HH, Guo W. Disability adjusted life year (DALY): A useful tool for quantitative assessment of environmental pollution. Science of The Total Environment. 2015;511: 268-287.

[21] Central Statistical Office. Transport: Activity of results in 2014. Warszawa 2015. Available at: https://stat.gov.pl/files/gfx/portalinformacyjny/pl/ defaultaktualnosci/5511/9/14/1/transport_wyniki _dzialalnosci_2014.pdf [Accessed 19 August 2018].

[22] Central Statistical Office. Transport: Activity results in 2017. Warszawa 2018. Available at: https://stat.gov.pl/ obszary-tematyczne/transport-i-lacznosc/transport/ transport-wyniki-dzialalnosci-w-2017-roku,9,17.html\# [Accessed 20 November 2018]. 